\title{
THE EFFECT OF MANGANESE COMPOUNDS ON SOILS AND PLANTS
}

\section{A THESIS}

PRESENTED TO THE FACULTY OF THE GRADUATE SCHOOL

OF CORNELL UNIVERSITY FOR THE DEGREE OF

\author{
DOCTOR OF PHILOSOPHY
}

BY

EUGENE PEYTON DEATRICK

SEPTEMBER, 1917

Reprinted from Memoir No. 19, February, 1919, of Cornell University Asricultural 



\title{
THE EFFECT OF MANGANESE COMPOUNDS ON SOILS AND PLANTS
}

\author{
A THESIS \\ PRESENTED TO THE FACULTY OF THE GRADUATE SCHOOL \\ OF CORNELL UNIVERSITY FOR THE DEGREE OF \\ DOCTOR OF PHILOSOPHY
}

BY

EUGENE PEYTON DEATRICK

SEPTEMBER, 1917

Reprinted from Memoir No. 19, February, 1919, of Cornell University A\&ricultural Experiment Station 


$$
S^{5^{3}} \Delta^{x}
$$

In exchange

Conell uni.

Sep.2'19. 


\section{CONTENTS}

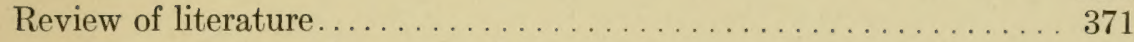

Experiments with water cultures . . . . . . . . . . . . 371

Experiments with soil cultures . . . . . . . . . . . . . . . . 374

Experiments with soil fungi and bacteria . . . . . . . . . 377

Summary.............................. 378

Experimental work . . . . . . . . . . . . . . . . . . 379

Scope of present study . . . . . . . . . . . . . . . . . 379

Effect of manganese compounds on wheat seedlings grown in water cultures............................. 379

Effect of manganese compounds on wheat grown in soil . . . . . 383

Manganese content of yellow leaves................. 387

Relation of manganese to the oxidizing power of soils . . . . . . 388

Adsorption of manganese . . . . . . . . . . . . . . 390

Oxidation by plant roots. . . . . . . . . . . . . . . . . 393

Effect of manganese sulfate on soil bacteria............ 395

Ammonification ........................... 396

Nitrification . . . . . . . . . . . . . . . . . . . . . . 397

Conclusions. . . . . . . . . . . . . . . . . . . . . . . . . . . 398

Literature cited . . . . . . . . . . . . . . . . . . . . . . 399 

THE EFFECT OF MANGANESE COMPOUNDS ON SOILS AND PLANTS 



\title{
THE EFFECT OF MANGANESE COMPOUNDS ON SOILS AND PLANTS
}

\author{
E. P. Deatrick
}

Experimental evidence has shown that phosphorus, sulfur, potassium, calcium, magnesium, iron, carbon, hydrogen, oxygen, and nitrogen are essential to the normal growth and development of plants. Other elements, including manganese, are almost universally found in soils and plants, and this fact has led some investigators to assume that they perform important physiological functions. The weight of evidence, however, seems to indicate that the benefit following applications of a manganese compound to soil is due to its stimulative, indirect action either on the plant or on the soil, and manganese is therefore usually designated as a catalytic fertilizer.

The investigation here recorded was undertaken for the purpose of acquiring information regarding the specific effect of manganese compounds in increasing plant growth; in other words, to determine whether manganese is a direct plant stimulant, whether it increases the available food supply in the soil, or whether both these factors are operative. The direct stimulative or deleterious effect of a substance on plant growth may be determined by growing the plant to be studied in water cultures of a pure nutrient solution. When the same kind of plant is grown in soil to which the substance to be studied is added, the effect is usually very much modified. In the soil culture the action must be considered as the sum of the effects directly and indirectly on soil and plant.

\section{REVIEW OF LITERATURE}

Experiments with water cultures

The effects of manganese on plants have been studied by growing seedlings in distilled water alone, and in distilled water to which nutrient salts were added.

Working with the distilled water cultures, investigators have observed both stimulative and toxic effects. Loew and Sawa $(1902-03)^{1}$ found that in the presence of manganese in toxic quantities the leaves lose their

\footnotetext{
1Dates in parenthesis refer to Literature cited, page 399.
} 
turgor and dry up, and no trace of new rootlets is apparent. In a solution containing 1000 parts per million of manganese sulfate, the leaves of barley plants faded to yellow and then turned brown. These investigators found also that barley became chlorotic and the roots turned brown in solutions containing only small quantities of manganese. McCool (1913) noted that a solution containing 15 parts per million of manganese in the form of chloride is injurious to field peas, and that a solution containing 30 parts per million prevents root growth entirely. Miss Brenchley (1914) found that manganese when present in strong concentrations exerts a toxic influence on higher plants.

On the other hand, several investigators have obtained plant stimulation in distilled water cultures containing small quantities of manganese. Micheels and De Heen (1906) obtained a pronounced stimulation in colloidal solutions of manganese. McCallum (1909) reported an acceleration of tuber formation when potatoes were treated with a solution of manganese chloride. Montemartini (1911), altho finding marked differences in the sensitiveness of plants, obtained increased growth with all plants used in his experiment. MeCool (1913) found slight stimulation, as shown by length of the roots of pea seedlings, but the leaves showed no effect.

The effects of manganese in solutions containing nutrient salts are similar to those obtained with distilled water cultures, but experiments show that the nutrients greatly reduce the toxicity of the manganese. McCool (1913) found that this reduction of toxicity is proportional to the concentration of the nutrient salts.

According to Miss Brenchley (1914),

the Rothamsted experiments supported Aso's work on the action of manganese sulphate on barley, concentrations of the salt above $1 / 100,000$ having a retarding influence on the growth, the roots being coloured brown and the leaves also showing discolouration. At an early stage in growth the lower leaves of the plants receiving the most poison began to be flecked with brown spots.

A solution containing 1350 parts per million of nutrient salts and 770 parts per million of manganese in the form of sulfate, reduced the yield 31 per cent. A solution containing but 0.01 of this amount of manganese developed brown roots after four weeks and reduced the yield 3 per cent.

In lower concentrations manganese was decidedly stimulative. Aso (1902-03) found that manganese stimulated the growth of a number of plants. The solutions which he used contained 0.5 per cent of nutrient 
salts and 0.02 per cent of manganese sulfate in one series, and 0.05 per cent of nutrient salts and 0.002 per cent of manganese sulfate in the other series.

Tottingham and Beck (1916) reported increased yields of wheat grown in nutrient solutions containing small quantities of manganese chloride.

Various views are held regarding the cause of the stimulation on the one hand and of the toxicity on the other. Loew and Sawa (1902-03) suggest that the stimulation by manganese is related to the oxidation of toxic substances within the plant leaf. They assert that certain noxious by-products are formed in the leaf, and that in reality sunlight retards growth. They state: "It is in the absence. of light that growth proceeds and the products of the sun's work are chiefly consumed." Protoplasm oxidizes the carbohydrates formed, while the noxious byproducts, probably members of the benzene group, are oxidized by enzymes, whose action is increased by the presence of manganese.

Many investigators find that the action of enzymes is in some way related to the presence of manganese. Kastle (1910) writes at length on manganese in its relation to the oxidizing ferments. It has been shown by Bertrand, he states, that the oxidizing power of lacease (from lucerne) is associated with the manganese content. He regards this element as the co-ferment, or activator, of laccase, just as hydrochloric acid is the co-ferment of pepsin. The oxidation of organic compounds, such as hydroquinon, by the oxygen of the air, is accelerated by the presence of manganese and varies with the form of the salt, being greater with the salts of the organic acids. These salts are "most easily hydrolyzable"; thus,

$$
R^{\prime \prime} \mathrm{Mn}+\mathrm{HOH}=R^{\prime \prime} \mathrm{H}_{2}+\mathrm{MnO} .
$$

The manganous oxide formed is "spontaneously oxidizable." In this oxidation, "molecular oxygen is split into two atoms, one of which combines with the manganous oxide to form the peroxide, the other going to oxidize the hydroquinon "; thus,

$$
\begin{aligned}
& \mathrm{MnO}+\mathrm{O}_{2}=\mathrm{MnO}_{2}+\mathrm{O} \text {, and } \\
& \mathrm{C}_{6} \mathrm{H}_{4}(\mathrm{OH})_{2}+\mathrm{O}=\mathrm{C}_{6} \mathrm{H}_{4} \mathrm{O}_{2}+\mathrm{HOH}
\end{aligned}
$$

In the presence of an acid, $R^{\prime \prime} \mathrm{H}_{2}$ is unstable and is capable of oxidizing more hydroquinon. Thus the manganese salt is regenerated. "According to this conception the manganese would be the really active element 
of the oxidase, so far as the activation and transfer of oxygen is concerned, whereas the acid albuminoid radicle would impart to the ferment its other properties, such as its conduct toward heat, solubility, etc."

Manganese has been found to activate animal ferments. Considerable work has been done on the oxidizing power of colloidal solutions of manganese, which are described by Kastle as artificial ferments.

The reports of numerous investigators indicate that a relation exists between the presence of manganese and the production of chlorophyll. Van Dam (1907) states that seerls soaked in a solution of manganese sulfate yield plants which develop greener leaves than normally. Jadin and Astruc (1912) report that manganese constantly occurs in the ash of plants and that the chlorophyll-bearing parts contain the greatest proportion of this element. Mameli (1912) found that chlorophyll is produced in some of the lower plants only when manganese is added to the nutrient media. Pugliese (1913) states that there is an optimum ratio for iron and manganese, which he gives as 1:2.5. Mazé (1914) has described a special type of chlorosis due to the lack of manganese; a large amount in the plant also causes chlorosis. Gile (1916) is of the opinion that " manganese chlorosis may be due in part to a deficiency of iron in the plant, induced by the action of manganese in the plant or in the soil, and in part to a direct toxic action of the manganese." Johnson (1917) finds that the toxic effect of manganese on pineapples appears to be " due to a depression in the assimilation of iron," and has worked out a commercially successful method of counteracting the toxic effect by supplying iron thru the leaves.

\section{Experiments with soil cultures}

A large number of experiments are reported in which manganese salts have been applied to soil as a fertilizer. The results are somewhat contradictory.

Von Feilitzen (1907) found that manganese sulfate did not increase the yield of oats pereeptibly. Pfeiffer and Blanck (1912), after experimenting with various salts and plants, deciled that their results were not conclusive. They state that, while increased yiclds were occasionally obtained, the salts of manganese should not be recommended for general use as a fertilizer. This opinion is held also by Sullivan and Robinson (1913), who advised that manganese should not be used "in any way 
other than in experimentation and as a fertilizer complementary to the usual chemical fertilizers." Masoni (1916) experimented with several manganese salts. Altho the chloride and the sulfate seemed to give a certain advantage, he believed the results were too small to indicate definitely the specific effect on the growth of the plants tested. Ehrenberg and Schultze (1917) state that experiments covering several years show that under many sorts of conditions neither a favoring nor an inhibitory action of manganese compounds on the growth of plants is demonstrable. At the Woburn station, however, Voelcker (1904) observed that manganese iodide, applied at the rate of 50 pounds to the acre, was very toxic to the growth of barley.

On the other hand, some surprising results have been obtained from the use of manganese salts. Javillier (1908) states that comparatively small quantities of this element have been sufficient to increase the yields of certain crops from 25 to 50 per eent. He believes there is no doubt that manganese compounds, particularly the sulfate, may be used advantageously as a complementary manure. Loew and Honda (1904-05) report an increase of 50 per cent in Cryptomeria japonica from fertilizing with manganese sulfate. With the use of the same salt Ray and Pradier (1909) were able to increase the yield of apricots 23 per cent. Bartmann (1910) cites Marre as having secured an increase of 60 per cent in some crops. Numerous other investigators have reported data indicating that manganese is a fertilizer of decided value.

A number of investigators, including Nagaoka (1906-08), and Skinner and his co-workers $(1914,1916)$, report data which are apparently contradictory. Nagaoka (1906-08) reported that in 1902 manganese sulfate applied at the rate of 70 pounds to the acre, increased the yield of rice 37 per cent; the following year the residual effect was considerable; in 1904 the season was "exceptionally favorable," but the treated plats again surpassed the checks; in 1905 the experiment was repeated, but that year the yield was greatly decreased. Skinner and Sullivan (1914) reported their work on the action of manganese in soils; they found that the growth of wheat was increased when various salts were added to a soil described as an unproductive sandy loam, while on a productive loam the salts had no stimulating effect.

Further experiments were reported by Skimner and Reid (1916), who state that "in a six-years field test of manganese sulphate used at the 
rate of 50 pounds per acre on an acid silty clay loam, its effect each year was not beneficial to the crops grown." During the following years of experimentation the yields of the crops were increased. The soil had been found to be very acid, and large quantities of calcium carbonate were applied.

It appears that the reaction of the soil is a determining factor in the action of manganese. Nagaoka (1906-08) notes that the soil increases in acidity with the continued application of manganese sulfate. Rousset (1909) cites Malpeaux as securing contradictory results with both the sulfate and the chloride of manganese, but favorable results with the carbonate and the oxide applied in combination with marl.

Some results have been obtained, however, which point to a decreased stimulation when manganese is applied with some form of calcium. According to Uchiyama (1907), "A manurial mixture of a nearly neutral reaction, exerts the best effect. Manures of decisive alkaline or acidic nature on the other hand are not so favorable, since the former interferes with the effect of the manganese salt, while the latter are not suitable for the growth of most plants." Chittenden (1915-16) observed the same effect; he states that in two out of three cases manganese sulfate alone increased the yield, while the addition of lime to the manganese sulfate decreased the yield.

Many of the apparently inconsistent reports are explainable when complete data regarding the experiment are available. Some of the applications are too low. Others, as that of Crochetelle (1913), who applied an excessive amount (2000 pounds to the acre) of manganese sulfate to a "calcareous clay," are high yet stimulative.

References to the change which manganese compounds may undergo when added to soils are numerous. Nottin (1912) found that manganese is adsorbed like potassium or ammonia, and is precipitated by calcium carbonate and organic matter; the demanganization of water by calcium carbonate, and the precipitation of manganese found in dolomitized limestones, indicate that, in alkaline soils at least, the soluble salts of manganese are changed to oxides. In the soil solution, manganese probably occurs in the form of the bicarbonate, as Vincent (1916) concludes. Regarding solubility, Masoni (1916) states that the organic acids are particularly active in dissolving manganese. He claims that the bchavior of the carbonates, sulfates, and oxides of manganese may be explained as phenomena of hydrolysis and of successive oxidation and reduction. 
According to Schreiner, Sullivan, and Reid (1910:37), "soils may have practically the same amount of manganese and still vary greatly in oxidizing power, so oxidation in soils, if due to manganese, depends on the nature of the manganese as much as on the amount." The salts of manganese added to soils which were low in this element and had "very little oxidizing power," did not increase their power to oxidize aloin. Experiments to learn the effect on oxidation of the addition of hydroxy acids and salts to manganese compounds in the soil, led these authors to state (page 56 of reference cited): "This oxidation appears to be mainly nonenzymotic, the result of interaction between inorganic constituents and certain types of organic matter. It may also be brought about by organic matter in a state of autoxidation and by inorganic oxygen carriers, such as manganese and iron. Both processes activate oxygen."

According to Sullivan and Reid (1912:28), "That the catalytic power of the soil is correlated to some degree with the manganese content of the soil is evident." A comparison of soils of varying manganese content, and the failure of the addition of manganese salts to increase the catalytic power of soils that were poor catalyzers even tho the content of manganese was high, led these investigators to state that factors other than the "total amount of manganese must he the determinants." They suggest that either the nature of the manganese compound or the nature of the associated organic matter is more important than the amount of manganese.

\section{Experiments with soil fungi and bacteria}

Altho the experimentation is meager, the weight of evidence supports the conclusions of Bertrand (1909) that manganese stimulates the growth of fungi. Loew and Sawa (1902-03), however, found no stimulation, and they have written at length on the difference of the behavior of manganese on the growth of phanerogams.

Kelley (1912) conclucled that nitrification took place more rapidly in the soil high in manganese, while ammonification was about equal in soils cf either high or low manganese content. Leoncini (1910) and Montanari (1914) have found that manganese increases the activity of nitrifying bacteria.

Brown (Brown and Minges, 1916) applied various salts of manganese to soil cultures, and concluded from his data that "if manganese salts in small quantities increase crop yields on a soil, that increase may be 
due in part at least to a beneficial effect on ammonification and nitrification." If, on the other hand, the salts " restrict crop growth, that restriction may be due in part to a depression of bacterial activity."

Greaves (1916) has recently published his results. He states that with the possible exception of the chloride, all the manganese salts tested were strong stimulants to the ammonifying organisms of the soil. At maximum stimulation, 25 per cent more ammonia accumulated than in the normal soil.

Olaru (1915) states that the nitrogen-fixing power of bacteria from legumes is greatly increased by manganese. Gregario (1916) finds that mannitol bouillon containing 60 parts per million of manganese in the form of the chloride and inoculated with Bacillus radicicola fixes three times as much nitrogen as do the checks; a concentration of 200 parts per million retards the fixation. Furthermore, he finds that Clostridium pasteurianum, which normally is not a free fixer, becomes capable of fixing nitrogen in the presence of manganese. Similar results have been obtained with Azotobacter chroococcum.

\section{Summary}

Much of the evidence in the foregoing reports is contradictory. The results would be more intelligible if complete data regarding the experiments were given. The applications of manganese salts to soils have been made without any apparent consideration of the type of soil. Such factors as soil type, the presence of calcium, and the crop to be grown, are factors that determine the action of a given application. Large applieations on a sandy loam are detrimental, while the same applieations on a clay loam or on a soil high in calcium would in all probability be stimulative.

The rôle of calcium seems to be a complex one. If the manganese were stimulative in the soluble form, the addition of calcium would precipitate the manganese and prevent the stimulation. If, on the other hand, the manganese were present in such concentration as to be toxic, the addition of calcium would be beneficial, not only by causing precipitation of the manganese but also by increasing the oxidizing power of the soil by such precipitation.

Altho the evidence is in many respects inconclusive, the following statements seem to be justified by this review:

1. Manganese is universally distributed in small quantities in soils and plants. 
2. The majority of experiments indicate that, as Miss Brenchley (1914) states, "manganese exerts a toxic influence upon the higher plants, if it is presented in high concentration, but, in the absence of great excess of the manganese compounds, the poisoning effect is overshadowed by a definite stimulation."

3. The toxicity of manganese is reduced by nutrient solutions and by soil.

4. Manganese compounds have been associated with the catalytic power of soils and with the oxidizing power of soils and plants. Comparatively large yields have been obtained with manganese fertilization under neutral or alkaline soil conditions, and the yields have been correlated with the oxidizing power of the soil. The stimulation of plants has in part been explained as due to increased activity in the metabolic processes within the leaf.

5. A stimulation of the ammonification and nitrification in soils has also been reported.

\section{EXPERIMENTAL WORK \\ Scope of present study}

In order to test the effect of manganese salts on the growth of plants, the weight of wheat seedlings grown in manganese solutions of varying concentrations (both in the presence and in the absence of nutrient salts) was compared with the weight of plants grown in cultures containing no manganese. The concentrations producing stimulation were then used as a basis for the applications in the experimental work conducted to test the manurial value of manganese when applied to soils. Dunkirk silt loam was treated with various manganese salts and planted with wheat. An attempt to explain the result's obtained led to a study of the oxidizing, ammonifying, and nitrifying powers of soils treated with salts of manganese.

Effect of manganese compounds on wheat seedlings grown in water cultures

Wheat seedlings (Jones' Paris Prize 106-43) from seeds germinated in running tap water were allowed to attain a growth of about eight centimeters, and were then transferred to culture containers. These were salt-mouth bottles of a capacity of 250 cubic centimeters, fitted with four-holed corks and wrapped in black paper. Each series was set up 
in quadruple and was run for a period of two or four weeks. The nutrient solutions were made up from the following formulae:

Salt 1. Calcium nitrate............... 27

Salt 2. Magnesium sulfate.............. 6 grams

Salt 3. Potassium phosphate (monobasic).... 15 grams

Salt 4. Ferric sulfate................. 0.5 gram

Salt 5. Potassium chloride............ 7.5 grams

Salts 1 and 5 were dissolved together in 3 liters of water; salt 2 was dissolved in $1 \frac{1}{2}$ liters, as was also salt 4 , and both of these were mixed with salts 1 and 5 . To the mixture was then added salt 3 , after it had been dissolved in 3 liters of water. The total quantity was then inereased to 10 liters by adding 1 liter of water. This solution contains 4656 parts per million of salts.

The wheat seedlings were placed in cultures containing 10,20, 100, 200,400 , and 1000 parts per million of manganese in the form of manganese sulfate, and were harvested after remaining in the greenhouse for four weeks. The results are given in table 1 :

TAble 1. Wheat Seedings (Endosperms not Removed) Grown in Solutions of Manganese Sulfate. No Nutrients Present

\begin{tabular}{|c|c|c|c|c|c|c|}
\hline \multirow{2}{*}{$\begin{array}{l}\text { Parts per million } \\
\text { of manganese }\end{array}$} & \multicolumn{2}{|c|}{$\begin{array}{c}\text { Length } \\
\text { (in centimeters) }\end{array}$} & \multicolumn{2}{|c|}{$\begin{array}{l}\text { Weight of four plants } \\
\text { (in grams) }\end{array}$} & \multirow{2}{*}{$\begin{array}{c}\text { Total } \\
\text { dry } \\
\text { weight }\end{array}$} & \multirow{2}{*}{$\begin{array}{l}\text { Relative } \\
\text { weights }\end{array}$} \\
\hline & Leaves & Roots & Leaves & Roots & & \\
\hline 0 & 11.7 & 18.2 & .0784 & .0514 & .1298 & 100 \\
\hline 10 & 10.6 & 10.3 & .0940 & .0460 & 1400 & 108 \\
\hline 20 & 11.5 & 5.6 & .0967 & .0319 & .1286 & 99 \\
\hline 100 & 10.6 & 4.2 & .0658 & .0211 & .0869 & 67 \\
\hline 200 & 12.4 & 4.6 & .0873 & .0163 & .1036 & 80 \\
\hline 400 & 10.9 & 3.7 & .0770 & .0222 & .0992 & 76 \\
\hline 1000 & 9.8 & 3.8 & .0641 & .0171 & .0812 & 63 \\
\hline
\end{tabular}

As shown in table 1 , solutions of manganese sulfate containing no nutrients were found to be toxic. All the manganese cultures, at the termination of the experiment, might be characterized as dead or dying. There was no great increase in growth, if any increase at all, even in the lowest concentration. The total dry matter was reduced in all cases except with a concentration of ten parts per million. The first symptom of the toxicity of manganese is the yellowing of the tips of the lower leaves. 
Then bleaching occurs in small patches, which reden, dry, and turn brown. The intensity of this chlorotic conclition decreases with the decrease in the concentration of the manganese. The roots of the plants grown in concentrations of 1000 parts per million turned brown in spots, especially at the tips, within four days. This browning occurred on the roots of all the plants except the checks, the length of time before the browning appeared being proportional to the concentration of the manganese.

The toxic effect was not so great in cultures of manganese sulfate containing nutrient salts (4656 parts per million) as in pure solutions, as is shown in table 2 :

Table 2. Manganese Sulfate Added to Nutrient Solutions Containing 4656 Parts per Milition of Nutrient Salts

\begin{tabular}{|c|c|c|c|c|c|c|}
\hline \multirow{2}{*}{$\begin{array}{l}\text { Parts per million } \\
\text { of manganese }\end{array}$} & \multicolumn{2}{|c|}{$\begin{array}{c}\text { Length } \\
\text { (in centimeters) }\end{array}$} & \multicolumn{2}{|c|}{$\begin{array}{l}\text { Weight of four plants } \\
\text { (in grams) }\end{array}$} & \multirow{2}{*}{$\begin{array}{l}\text { Total } \\
\text { dry } \\
\text { weight }\end{array}$} & \multirow{2}{*}{$\begin{array}{l}\text { Relative } \\
\text { weights }\end{array}$} \\
\hline & Leaves & Roots & Leaves & Roots & & \\
\hline 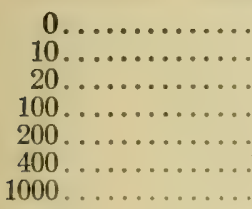 & $\begin{array}{l}19.4 \\
17.8 \\
19.2 \\
21.2 \\
20.5 \\
20.7 \\
16.0\end{array}$ & $\begin{array}{r}12.0 \\
15.4 \\
15.6 \\
14.0 \\
12.8 \\
9.3 \\
5.9\end{array}$ & $\begin{array}{l}1713 \\
.2951 \\
.2668 \\
.2383 \\
.2250 \\
.2020 \\
.1581\end{array}$ & $\begin{array}{l}.0742 \\
.2033 \\
.1781 \\
.1294 \\
.1052 \\
.0780 \\
.0459\end{array}$ & $\begin{array}{l}.2455 \\
.4984 \\
.4449 \\
.3677 \\
.3302 \\
.2800 \\
.2040\end{array}$ & $\begin{array}{r}100 \\
203 \\
181 \\
150 \\
135 \\
114 \\
83\end{array}$ \\
\hline
\end{tabular}

This demonstrates the ameliorating effect of the nutrient salts in overcoming or reducing the toxicity of a plant poison. At 1000 parts per million the total dry matter was reduced, but it equaled the check at 400 parts per million and inereased with a decrease in the concentration of the manganese. The yellowing of the tips of the leaves at 1000 parts per million commenced in nine days. The browning of the roots was not observed in any of the cultures except those of greatest manganese content.

A second series of cultures was run in which the chloride, the earbonate, and the dioxide of manganese were used in aldition to the sulfate. The seedlings of the first series, reported as having grown in solutions containing no nutrient salts, were in reality not grown in the absence of other elements. That the effect of the storage food in the endosperms is a factor in work of this nature, is suggested by MeCool (1913), who states:

Pea seedlings [cotyledons not removed] that have been grown for ten days in distilled water, tap water, and full nutrient solution, respectively, are much more resistant to the 
poisonous influence of manganese than those that are transferred from germinating pans and placed immediately in solutions of manganese. The nature of the medium used in this preliminary treatment - that is, whether distilled water, tap water, or full nutrient solution has no visible effect on the resisting power of the plants."

The seeds in this second series, consequently, were germinated as before, but when the scedlings were about eight centimeters high the endosperms were pinched off. This was done to eliminate as much as possible the influence of the storage food. The concentration of the nutrient solution was but one-fifth of that used in the previous series of cultures.

The average dry weight of the wheat seedlings at the time of setting up the eultures was determined, so that the effect of the manganese solutions might be the more accurately ascertained. The results are given in tables 3 and 4 :

Table 3. Wheat Seedlings (Endosperms Removed) Grown in Solutions of Manganese Salts. No Nutrients Present

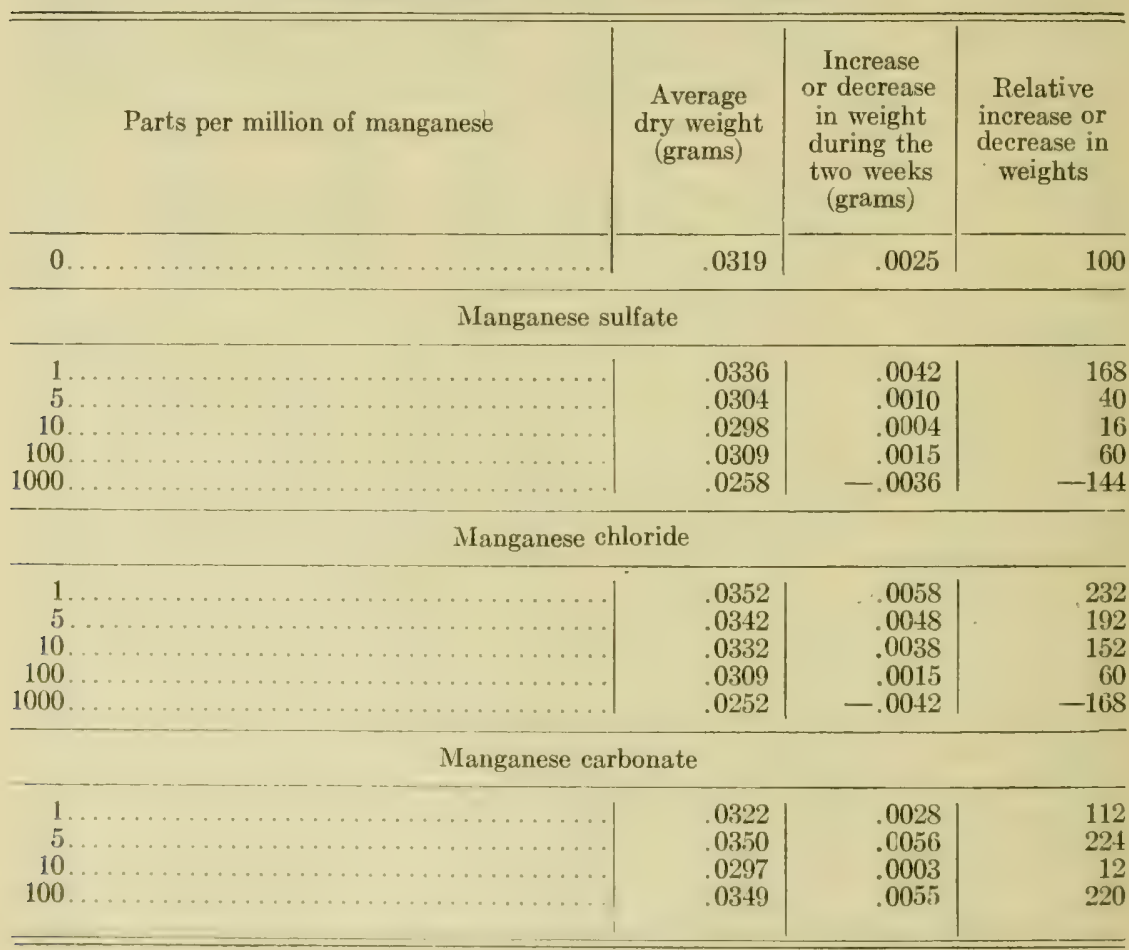


The Effect of Manganese Conipounds on Solls and Plants 383

Table 4. Manganese Salts Added to Nutrient Solutions Containing 961 Parts per Million of Nutrient Salts

\begin{tabular}{|c|c|c|c|}
\hline Parts per million of manganese & $\begin{array}{l}\text { Average } \\
\text { dry weight } \\
\text { (grams) }\end{array}$ & $\begin{array}{l}\text { Increase } \\
\text { in weight } \\
\text { during the } \\
\text { two weeks } \\
\text { (grams) }\end{array}$ & $\begin{array}{l}\text { Relative } \\
\text { increase in } \\
\text { weights }\end{array}$ \\
\hline$\ldots \ldots \ldots$ & 0367 & .0073 & 100 \\
\hline \multicolumn{4}{|c|}{ Manganese sulfate } \\
\hline 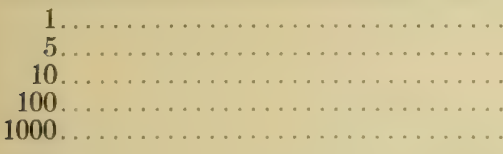 & $\begin{array}{l}.0392 \\
.0404 \\
.0423 \\
.0400 \\
.0368\end{array}$ & $\begin{array}{l}.0098 \\
.0110 \\
.0129 \\
.0106 \\
.0066\end{array}$ & $\begin{array}{r}134 \\
151 \\
177 \\
145 \\
90\end{array}$ \\
\hline \multicolumn{4}{|c|}{ Manganese chloride } \\
\hline $\begin{array}{r}1 \\
5 \ldots \ldots \ldots \\
10 \ldots \ldots \ldots \\
100 \ldots \ldots \ldots\end{array}$ & $\begin{array}{l}.0385 \\
.0419 \\
.0395 \\
.0387 \\
.0320\end{array}$ & $\begin{array}{l}.0091 \\
.0125 \\
.0101 \\
.0093 \\
.0026\end{array}$ & $\begin{array}{r}125 \\
171 \\
138 \\
127 \\
36\end{array}$ \\
\hline \multicolumn{4}{|c|}{ Manganese carbonate } \\
\hline 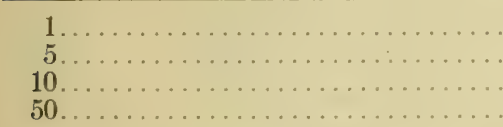 & $\begin{array}{l}.0367 \\
.0376 \\
.0387 \\
.0455\end{array}$ & $\begin{array}{l}.0073 \\
.0082 \\
.0093 \\
.0161\end{array}$ & $\begin{array}{l}100 \\
112 \\
127 \\
220\end{array}$ \\
\hline
\end{tabular}

It will be noticed that by this procedure it has been possible to show an actual decrease in the weight of the seedlings grown in the solutions of highest concentrations of the sulfate and the chloride.

An examination of tables 3 and 4, giving the results of this series of experiments, shows that these results agree in general with those of the first series; that is, as the concentration of the manganese decreases, the total dry weight increases. The figures show clearly the greater toxic effect of the manganese in the ahsence of the endosperm. The results here reported agree closely with those of Miss Brenchley (1914).

Effect of manganese compounds on wheat grown in soil

The determination of the effect of a given factor when added to the soil is complex. The effect of this factor on the growth of plants is but 
an indication of its resultant effect on the various activities in a complex medium. It was therefore deemed advisable to determine, in the first place, whether the addition of manganese sulfate to soil cultures inhibits its power to function as in the case of water cultures. Consequently, wheat was grown on soil to which manganese sulfate had been added in varying amounts.

In this, as well as in other soil experiments, the soil used was Dunkirk silt loam, obtained near the experimental plats of Caldwell Field. The results of the chemical and mechanical analyses are given in tables 5 and 6 , respectively:

Table 5. Chemical (Bulk) Analysis of Dunkirk Silt loam

\begin{tabular}{|c|c|c|}
\hline Constituent determined & $\begin{array}{l}\text { Surface } \\
1 \text { to } 12 \text { inches } \\
\text { (per cent) }\end{array}$ & $\begin{array}{l}\text { Subsoil } \\
12 \text { to } 24 \text { inches } \\
\text { (per cent) }\end{array}$ \\
\hline Nitrogen $(\mathrm{N})$. & 0.186 & 0.082 \\
\hline Organic carbon (C) & 1.670 & 0.440 \\
\hline Carbon dioxide $\left(\mathrm{CO}_{2}\right)$ & Trace & 0.260 \\
\hline Calcium oxide $(\mathrm{CaO})$. & 0.430 & 0.830 \\
\hline Magnesium oxide (MgO) & 0.450 & 0.690 \\
\hline Potassium oxide $\left(\mathrm{K}_{2} \mathrm{O}\right) \ldots$ & 1.740 & 2.110 \\
\hline Sodium oxide $\left(\mathrm{Na}_{2} \mathrm{O}\right)$.. & 1.090 & 1.280 \\
\hline Phosphoric anhydride $\left(\mathrm{P}_{2} \mathrm{O}_{5}\right)$. & 0.123 & 0.126 \\
\hline Manganese oxide $\left(\mathrm{Mn}_{0} \mathrm{O}_{4}\right) \ldots$ & 0 & 0 \\
\hline
\end{tabular}

Table 6. Mechanical Analysis of Dunkirk Silt Loam

Fine gravel

Coarse sand

Medium sand

Fine sand.

Very fine sand

Silt

Clay

The soil was procured in quantity, was allowed to partially dry out in the air, and was then passed thru a 2-millimeter sieve. After treatment with manganese sulfate the soil was placed in small wire baskets, 350 
grams to a basket. The baskets were paraffined and a sand mulch was placed on the surface. Six baskets of each treatment were set up, four of which were planted with wheat seedlings about 10 centimeters high. There were four seedlings in each basket. The baskets were carried to the greenhouse, where they remained for a period of three months. During that period they received such applications of distilled water, from time to time, as would bring the soil up to the original moisture content of 25 per cent (dry basis). On May 3, 1916, the crop was harvested, and the plants were dried, weighed, and analyzed for manganese. The results are given in table 7 :

Table 7. Whrat Grown for Three Months on Dunkirk Silt Loam Treated with Manganese Sulfate

\begin{tabular}{|c|c|c|}
\hline Parts per million of manganese added & \begin{tabular}{|c|} 
Average weight \\
of seedlings \\
in each culture \\
(grams)
\end{tabular} & $\begin{array}{l}\text { Relative } \\
\text { weights }\end{array}$ \\
\hline 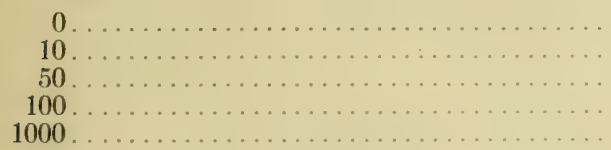 & $\begin{array}{l}2.70 \\
3.25 \\
2.80 \\
1.94 \\
2.05\end{array}$ & $\begin{array}{r}100 \\
120 \\
104 \\
72 \\
76\end{array}$ \\
\hline
\end{tabular}

An examination of the relative weights shows that the manganese is at least not prevented entirely from stimulating plant growth when it is added to soil. The stimulation at 10 parts per million was appreciable.

Another set of cultures was arranged on December 12, 1916. Two kilograms of air-dry soil, to which the various quantitics of manganese sulfate were added, was placed in wire baskets. These baskets then received a coating of paraffin and a sand mulch. Seven of the baskets received an application of calcium carbonate at the rate of 20,000 parts of $\mathrm{CaO}$ per million of soil. The soil was seeded to wheat and the moisture content was raised to 25 per eent (dry basis), where it was kept by the addition of distilled water from time to time. One month later the seedlings were thinned to five to a basket, and these were allowed to grow for seven and 
one-half months. The crop was harvested on July 3, 1917. The yields obtained are recorded in tables 8 and 9 :

Table 8. Wheat Growx for Seven and One-Half Months on Dunkirk Silt Loan Treated with Manganese Sulfate

\begin{tabular}{|c|c|c|c|c|}
\hline \multirow{2}{*}{ Parts per million of manganese added } & \multicolumn{2}{|c|}{ Weight of straw } & \multicolumn{2}{|c|}{ Weight of grain } \\
\hline & $\begin{array}{l}\text { Average } \\
\text { (grams) }\end{array}$ & Relative & $\begin{array}{c}\text { Average } \\
\text { (grams) }\end{array}$ & Relative \\
\hline $\begin{array}{l}0 . \\
0 . \\
50 .\end{array}$ & $\begin{array}{r}5.6 \\
5.0 \\
5.7 \\
\quad 3.5\end{array}$ & $\begin{array}{r}100 \\
89 \\
102 \\
62\end{array}$ & $\begin{array}{l}2.0 \\
4.0 \\
4.1 \\
2.3\end{array}$ & $\begin{array}{l}100 \\
200 \\
205 \\
115\end{array}$ \\
\hline
\end{tabular}

Table 9. Wheat Grown for Seven and One-Half Months on Dunkirk Silt Loam Treated with Manganese Sulfate and 20,000 Parts per Million of Calcium CarBONATE

\begin{tabular}{|c|c|c|c|c|}
\hline \multirow{2}{*}{ Parts per million of manganese added } & \multicolumn{2}{|c|}{ Weight of straw } & \multicolumn{2}{|c|}{ Weight of grain } \\
\hline & $\begin{array}{l}\text { Average } \\
\text { (grams) }\end{array}$ & Relative & $\begin{array}{l}\text { Average } \\
\text { (grams) }\end{array}$ & Relative \\
\hline 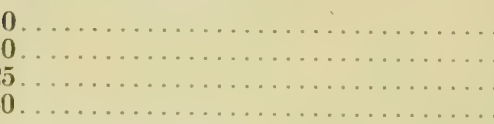 & $\begin{array}{l}1.7 \\
4.5 \\
4.9 \\
5.0\end{array}$ & $\begin{array}{l}100 \\
265 \\
288 \\
291\end{array}$ & $\begin{array}{l}1.7 \\
2.0 \\
1.8 \\
2.1\end{array}$ & $\begin{array}{l}100 \\
118 \\
106 \\
123\end{array}$ \\
\hline
\end{tabular}

The effect of the manganese in these cultures is not apparent when the yields are considered. Practically all the yields of the soil treated with manganese are somewhat higher than those treated with calcium. The yicld for the calcium carbonate check is strikingly low, for which no reason can be assigned by the writer. Greater differences, however, than those that appear in the data of table 9, were noted at an earlier stage of growth. It was observed that a majority of the manganese plants headed hefore the calcium-manganese plants did. In this respect it would seem that the calcium had interfered with the action of the manganese, 
Other investigators have stated that the effect of manganese on yield is not marked. While Bertrand (1909) notes that the favorable results of manganese are not apparent until harvest time, Miss Brenchley (1914) states that there is a retarding effect on the ripening of the grain but not on the yield. Takeuchi (1909-13) reports that the control plants of flax were behind the manganese plants in growth and flowering. Aso (1904-05) found that rice treated with manganese flowered four days earlier than did the checks. Salomone (1907) states that the stimulation of the vegetative portion of plants is greater than that of the grain. Comparison of the data in tables 7 and 8 shows that greater differences in the yields were obtained when the plants were harvested before they matured.

\section{Manganese content of yellow leaves}

Several investigators have reported that the yellow leaves of manganese plants contain more manganese than do the green leaves. The leaves of the plants grown on soil treated with manganese sulfate (page 385) were analyzed for their manganese content by the colorimetric method described in Bulletin 31 of the United States Bureau of Soils. The results are given in table 10 :

Table 10. Analyses of Leaves of Wheat Grown on Sorl Treated with Manganese Sulfate

\begin{tabular}{|c|c|c|c|}
\hline \multirow{2}{*}{ Parts per million of manganese added } & \multicolumn{3}{|c|}{$\begin{array}{l}\text { Manganese (in parts per million grams } \\
\text { of dry matter) in }\end{array}$} \\
\hline & $\begin{array}{l}\text { Green } \\
\text { leaves }\end{array}$ & $\begin{array}{l}\text { Yellow } \\
\text { leaves }\end{array}$ & $\begin{array}{l}\text { Medium } \\
\text { yellow } \\
\text { leaves }\end{array}$ \\
\hline $\begin{array}{r}0 \\
10 \\
50 \\
100 \\
1000\end{array}$ & $\begin{array}{r}\text { Trace } \\
\text { Trace } \\
\text { Trace } \\
1.15 \\
1.95\end{array}$ & $\begin{array}{r}\text { Trace } \\
\text { Trace } \\
3.8 \\
7.25 \\
11.25\end{array}$ & $\begin{array}{r}\text { Trace } \\
\text { Trace } \\
1.22 \\
3.37 \\
3.12\end{array}$ \\
\hline
\end{tabular}

If Aso (1902-03) is correct in stating that the colorimetric tests for the oxidizing enzymes showed that "the yellowish leaves of the manganese plants gave reactions of higher intensity than the green leaves of the control plants," it seems that the intensity of these enzymes is proportional to 
the manganese content of the leaves. Woods (1899) states: "It has long heen known that chlorophyll could be readily converted by oxidation, into a yellow coloring matter, xanthophyll." While a moderate stimulation of the oxidizing power of the plant juices may result beneficially, an excessive stimulation may result in the oxidation of the chlorophyll.

\section{Relation of manganese to the oxidizing power of soils}

In some cases the lack of fertility in a soil has been shown to be due to the presence of certain organic substances injurious to plant growth. Schreiner and Shorey (1909) found that when such soils are well aërated they become productive. Schreiner, Sullivan, and Reid (1910:44) state that the addition of manganese to soils promotes "the most active oxidation," and "by its strong oxidizing power .... . would render the injurious material in the soil harmless or even beneficial and by the oxidation of inert or rather stable organic matter might cause" a liberation of plant food. A brief study of the effect of manganese salts on the oxidizing power of soils has therefore been made by the writer.

Portions of Dunkirk silt loam were sprayed with solutions of manganese chloride, manganese sulfate, potassium permanganate and suspensions of manganese earbonate, and manganese dioxide, in quantities such that the manganese added was in the proportion of 10, 100, and 1000 parts of manganese per million of dry soil. It was thought that by spraying the soil a more uniform distribution of the manganese could be obtained. Consequently the calculated amounts of the salts were added to sufficient water to bring the soil to 25 per cent moisture content (dry basis). The spraying was done with a simple atomizer, made with two pieces of glass tubing of different bore and a wide-mouth bottle. It was found that the physical condition of the soil was very good when the water was added in this way. A determination showed that the moisture lost in the form of mist and evaporation cluring the treatment was negligible. The soils were stored in glass quart jars for about seven months.

T'o test the oxidation in the soil, 50 cubie eentimeters of the following solution was added to 10 grams of the air-dried soil in a centrifuge tube:

10 grams aloin

200 cubic centimeters N/10 HCL,

790 cubic centimeters distilled water 
The tube was shaken for exactly one-half minute and was then placed in the centrifuge, which was started one minute after the solution was adderl. At the end of two minutes the electric current was turned off the centrifuge, and the speed was allowed to decrease gradually while a second test was started. Five minutes after the aloin was added in the first test, a portion of the supernatant liquid was poured into a colorimeter tube and the depth of color was compared with that of a standard.

This method will be found to differ considerably from that of Schreiner, Sullivan, and Reid (1910). The oxidation in the soils reported was so great that it was found necessary to use the method already described. The difference between the two methods is indicated by the following:

\begin{tabular}{|c|c|c|}
\hline & $\begin{array}{l}\text { Schreiner, } \\
\text { Sullivan, } \\
\text { and Reid }\end{array}$ & Deatrick \\
\hline $\begin{array}{l}\text { Time of test................. } \\
\text { Concentration of aloin solution } \\
\text { Flocculating agent ............ }\end{array}$ & $\begin{array}{l}2 \text { to } 3 \text { hours } \\
0: 125 \text { per cent } \\
\mathrm{C}_{2} \mathrm{H}_{5} \mathrm{OH}\end{array}$ & $\begin{array}{l}5 \text { minutes } \\
1.0 \text { per cent } \\
\text { HCL }\end{array}$ \\
\hline
\end{tabular}

The standard used in the writer's experiments was a solution of aloin which had been completely oxidized with either manganese dioxide or nitric acid. The results were calculated on the basis of the oxidation in the untreated soil as 100 .

The oxidation of phenolphthalin (made by reducing phenolphthalein with zine dust and sodium hydroxide) was also used as a means of testing the oxidation in soils. The data are given in table 11. These figures indicate definitely that the addition of manganese salts to soils increases the power to oxidize organic matter such as aloin and phenolphthalin. It appears that the salts which are the most effective are the permanganate, the chloride, and the sulfate.

While the treatment with manganese dioxide seems to have interfered slightly with oxidation, it has been observed that soils treated with precipitated manganese oxides, instead of the pulverized pyrolusite, oxidize aloin readily. The oxidation in the air-dry soil from the field was very weak. The increase due to the moisture treatment alone is very noticeable. Since the soil contains no manganese, this is due to some other cause. 
Table 11. Oxidation In Dunkirk Silt Loam Treated with Manganese Salts (Tests made seven months after treatment)

\begin{tabular}{|c|c|c|}
\hline \multirow{2}{*}{ Parts per million of manganese added } & \multicolumn{2}{|c|}{ Relative oxidation } \\
\hline & Aloin & Phenolphthalin \\
\hline 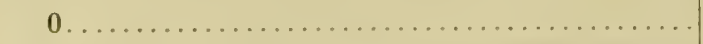 & 100 & 100 \\
\hline \multicolumn{3}{|l|}{ Potassium permanganate } \\
\hline 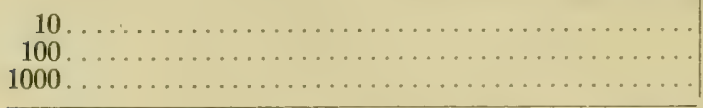 & $\begin{array}{l}101 \\
136 \\
444\end{array}$ & $\begin{array}{l}100 \\
120 \\
200\end{array}$ \\
\hline \multicolumn{3}{|l|}{ Manganese dioxide } \\
\hline 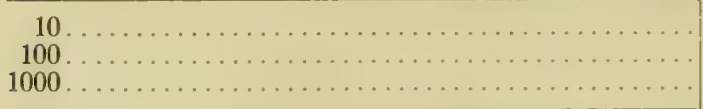 & $\begin{array}{l}93 \\
94 \\
95\end{array}$ & $\begin{array}{l}100 \\
100 \\
100\end{array}$ \\
\hline \multicolumn{3}{|l|}{ Manganese chloride } \\
\hline 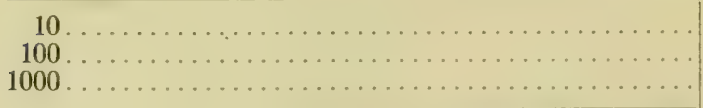 & $\begin{array}{l}105 \\
113 \\
171\end{array}$ & $\begin{array}{l}100 \\
125 \\
167\end{array}$ \\
\hline \multicolumn{3}{|l|}{ Manganese carbonate } \\
\hline 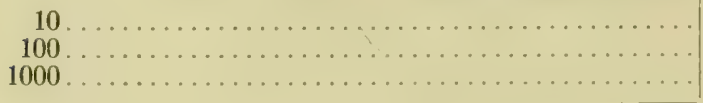 & $\begin{array}{l}105 \\
117 \\
128\end{array}$ & $\begin{array}{l}100 \\
100 \\
142\end{array}$ \\
\hline \multicolumn{3}{|l|}{ Manganese sulfate } \\
\hline 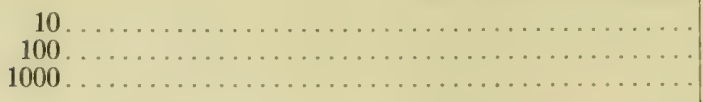 & $\begin{array}{l}105 \\
136 \\
233\end{array}$ & $\begin{array}{l}100 \\
130 \\
172\end{array}$ \\
\hline
\end{tabular}

\section{Adsorption of manganese}

It had been noted that soil to which manganese salts were added developed a power to oxidize aloin in proportion to the length of time that the salt was in contact with the soil. In order to test this more accurately, portions of soil, the moisture content of which had been held at 25 per cent for seven months, were treated with solutions of manganese sulfate. The data, given in table 12, indicate that oxidation does not develop at once, but that it is greatest in the soil in which the manganese has been present for the longest time. 
table 12. Effect of Duration of Contact of Soll with Manganese Sulfate, on the Oxidizing Power of the Soll

\begin{tabular}{|c|c|c|c|}
\hline $\begin{array}{l}\text { Parts per million of } \\
\text { manganese added }\end{array}$ & $\begin{array}{l}\text { Date when } \\
\text { manganese was } \\
\text { added }\end{array}$ & $\begin{array}{l}\text { Date when } \\
\text { oxidation was } \\
\text { determined }\end{array}$ & $\begin{array}{c}\text { Relative } \\
\text { oxidation }\end{array}$ \\
\hline $\begin{array}{r}10 \ldots \ldots \\
10 \ldots \ldots \\
1000 \ldots \ldots \\
1000 \ldots \ldots\end{array}$ & $\begin{array}{l}\text { April 3, } 1916 \\
\text { November 8, } 1916 \\
\text { April 3, 1916 } \\
\text { November 8, } 1916\end{array}$ & $\begin{array}{l}\text { November } 8,1916 \\
\text { November 8, } 1916 \\
\text { November 8, } 1916 \\
\text { November 8, } 1916\end{array}$ & $\begin{array}{l}100 \\
100 \\
185 \\
112\end{array}$ \\
\hline
\end{tabular}

In order to test the adsorptive power for manganese, four percolation cylinders were filled with Dunkirk silt loam, a kilogram to each cylinder. The cylinders were labeled A, B, C, and D, respectively. To soils C and $\mathrm{D}$ calcium hydroxide was added at the rate of 10,000 parts of $\mathrm{CaO}$ per million of soil. Soils A and B were untreated. A solution of manganese sulfate containing 1000 parts per million of manganese was then percolated thru the soils after they had been saturated with distilled water. Each successive 100 cubic centimeters of the percolate was analyzed for manganese by the colorimetric method described in Bulletin 31 of the United States Bureau of Soils. The manganese content of the percolates, expressed in parts per million, is given in table 13 :

Table 13. Manganese Content of Manganese Sulfate Solution (1000 Parts Per Million of Manganese) Percolated thru Dunkirk Silt Loam

\begin{tabular}{|c|c|c|c|c|}
\hline \multirow{2}{*}{$\begin{array}{l}\text { Successive } 100 \text {-cc. portions } \\
\text { of percolate }\end{array}$} & \multicolumn{4}{|c|}{ Manganese content in parts per million } \\
\hline & A & $\mathrm{B}$ & $\mathrm{C}$ & $\mathrm{D}$ \\
\hline 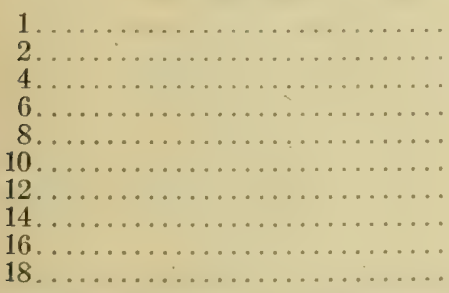 & $\begin{array}{r}0 \\
\text { Trace } \\
62 \\
500 \\
625 \\
715 \\
715 \\
715 \\
715 \\
770\end{array}$ & $\begin{array}{r}0 \\
111 \\
286 \\
400 \\
417 \\
455 \\
500 \\
525 \\
555 \\
475\end{array}$ & $\begin{array}{r}0 \\
0 \\
0 \\
\text { Trace } \\
62 \\
154 \\
218 \\
256 \\
357 \\
357\end{array}$ & $\begin{array}{r}0 \\
0 \\
0 \\
0 \\
\text { Trace } \\
92 \\
167 \\
143 \\
222 \\
91\end{array}$ \\
\hline
\end{tabular}


The soils treated with calcium hydroxide precipitated more manganese than did the untreated soils. In the case of soil C, one liter of the solution was passed thru it before any appreciable amount of manganese appeared in the percolate. On air-drying these soils, $\mathrm{C}$ and $\mathrm{D}$ were found to have an intensive oxidizing power as compared with $\mathrm{A}$ and $\mathrm{B}$.

Soils treated with 1000 parts per million of manganese in the form of pulverized pyrolusite were found not to have a strong oxidizing power. A solution of aloin, however, is rapidly oxidized when some of the pyrolusite is added to it. Colloidal manganese dioxide (from potassium permanganate and hydrochloric acid, purified by decantation) oxidizes aloin immediately. These phenomena, added to the fact that soils C and D developed the oxidizing power immediately in the presence of calcium, have led the writer to believe that the oxidation in soils due to manganese is due to the presence of manganese dioxide. In a solution of a manganese salt, manganic hydroxide is readily formed on the addition of an alkali. The formation of the oxide in soil to which a soluble manganese salt has been added, is directly proportional to the lime content, that is, the basicity of the soil. In the absence, of an excess of an alkali form of calcium, the formation of the oxide of manganese is slower, for the stability of the soluble salts, as the sulfate and the chloride, is of course greatest in an acid solution. The salts of the weak acids, however, are not so stable, and when adsorption phenomena play a part, the salts are unstable even in neutral media. Thus, if pure, fine sand is treated with a solution of manganese citrate, this instability is soon demonstrated by the browning of the sand. This has been found to be the case with sand so treated and stored in a jar. On exposure to air, sand treated with the acetate and the citrate has developed a slight brown color.

Schreiner, Sullivan, and Reid (1910) apparently tested their soils immediately after adding the manganese salts. These soils were probably deficient in lime, and therefore the addition of manganese did not increase oxidation. The increase noted when hydroxy acids were added to these soils may have been due to the formation of the organic salt of manganese and the subsequent precipitation of the oxide from the less stable salt.

The formation of the dioxide, and the oxidation phenomena in soils as described, are analogous to the formation of ealcium manganite (CaO. 
$\mathrm{MnO}_{2}$ ) and its use in the Weldon recovery process for the preparation of chlorine. The mixture of milk of lime and manganese chloride is termed Weldon, or manganese, mud.

\section{Oxidation by plant roots}

That roots of plants have an extracellular oxidizing power " may be demonstrated by the use of suitable chromogens," according to Schreiner and Reed (1909). In regard to their work on root oxidation in culture solutions containing alpha-naphthylamine, these investigators state (page 17 of reference cited) that " when the oxidation is performed by the growing roots of a plant, the oxynaphthylamine is deposited upon the surface of the roots in characteristic zones. . . . . The zone of primary meristematic cells immediately back of the root cap is marked by a distinct narrow band of color." The browning of the roots of wheat in solutions of manganese salts resembles the staining caused by the oxidation of alphanaphthylamine.

The reports of investigators indicate that such browning is characteristic of plants other than wheat, when grown in manganese solutions. This browning has been reported as consisting of a deposit of manganese dioxide. As far as can be ascertained by the writer, no proof has been offered for this statement. That the dioxide is formed, however, is indicated by the following: The black deposit is insoluble in water but dissolves in hydrochloric acid. When this solution is evaporated and the residue is fused with an alkali carbonate on platinum foil, the characteristic green color of the alkali manganate is developed. Furthermore, the blackened roots are capable of liberating chlorine from a solution of a chloride and sulfuric acid. If the plants thrive long enough in the manganese solution, the whole root system becomes blackened.

In writing of the deposit of manganese dioxide, Miss Houtermans (1912) states that the blackening is probably the result of enzymotic processes. The browning is the result of the oxidation which occurs on the surface of the root. The fixed alkali hydroxides precipitate from solutions of manganese salts manganous hydroxide, white, which reartily turns to brown manganic hydroxide in the air or in contact with other oxidizing agents. Since manganous hydroxide is formed in the solution of a manganese salt by hydrolysis, it seems that it is deposited on the roots, as such, and 
is there oxidized to a higher oxide, as the insoluble brown deposit. Soon after the heavy deposition of the oxide, disintegration of the root occurs.

Schreiner and Reed (1909) conclude that "the process of oxidation by roots is largely, if not entirely, due to the activity of a peroxidase produced by the roots." That the deposit is not caused merely by the instability of the manganese solutions in the presence of organic matter is indicated by the absence of any blackening on pieces of string or wood placed in them. A definite relation has been established between stimulants of this oxidizing power and stimulants of growth. Schreiner, Sullivan, and Reid (1910:9) state that "oxidation by plant roots is a factor which has considerable agricultural interest, especially from the viewpoint that such oxidation is able to change the organic matter in the medium in which the plant is growing and that processes promoting oxidation play a large part in the best methods of soil cultivation."

The effect of manganese on the oxidizing power of the roots of wheat seedlings was therefore investigated. Seedlings were set up as before in nutrient solutions (931 parts per million of salts) and grown for two weeks. Portions of these solutions were then treated with small quantities of the aloin solution and allowed to stand for twenty-four hours, and a comparison was then made of their relative oxidation. The results appear in table 14:

Table 14. Effect of Manganese Sulfate on Oxidation by Roots

\begin{tabular}{|c|c|c|}
\hline \multirow{2}{*}{ Parts per million of manganese } & \multicolumn{2}{|c|}{ Oxidation in solutions } \\
\hline & $\begin{array}{l}\text { With } \\
\text { plants }\end{array}$ & $\begin{array}{l}\text { Without } \\
\text { plants }\end{array}$ \\
\hline 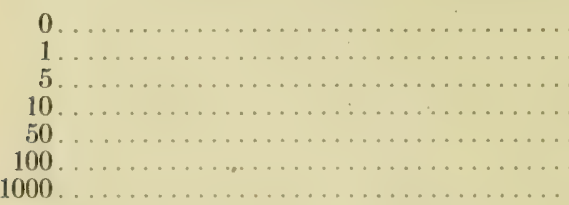 & $\begin{array}{l}100 \\
181 \\
191 \\
181 \\
244 \\
250 \\
206\end{array}$ & 16? \\
\hline
\end{tabular}

In every case the cultures in which plants had grown oxidized the aloin more than did those in which no plants were grown. In fact, the aloin was but faintly oxidized in the checks, and with the exception of the one containing the greatest quantity of manganese the degree of oxidation 
was considered as zero. When phenolphthalin was used as an indicator similar results were obtained, altho some trouble was experienced with these solutions because of the carbon dioxide content.

The bluing of gum guaiac was also used as an indication of the oxidizing power of the roots. The reagent, which was poured on the surface of the cultures, followed the path of the roots where it was oxidizerl. The objection has been raised that due consideration was not given to the oxidizing power of the manganese sulfate. It was found that a solution of gum guaiac is oxidized immediately by a solution of manganese sulfate containing approximately 10,000 parts per million of manganese. A solution of 1000 parts per million, however, gave only a slight bluing after three hours. Immediate bluing was obtained by the roots of plants grown in the presence of 10 parts per million of manganese in the form of the sulfate, while the bluing by the roots of the check plants was slow and not so intense.

\section{Effect of manganese sulfate on soil bacteria}

Numerous investigators have reported that the activity of the lower forms of plant life is increased by the presence of manganese salts. In order to test this point, cultures were set up to determine the effect of manganese sulfate on the ammonification of dried blood and the nitrification of ammonium sulfate in soil. These cultures were prepared from a fresh stock of Dunkirk silt loam, which had been passed thru a twomillimeter sieve and which contained 12 per cent (dry basis) of water. Portions of the soil each weighing 112 grams were placed in eight-ounce salt-mouth bottles. When properly treated the cultures were placed on the laboratory desk and covered with a moist pad, made of cheesecloth and cotton, to prevent the evaporation of water. It was found that in this way a large number of cultures could be kept at a constant moisture content with the expenditure of a minimum amount of labor. The cultures were run in quadruplicate and were incubated at room temperature. Two days after the cultures were set up, the soil in each bottle was stirred so as to insure uniformity in the distribution of the salts added. At the end of the incubation period, the soil in each bottle was stirred with 475 cubic centimeters of distilled water for three minutes and then allowed to settle for twenty minutes, and the supernatant liquid was filtered thru a Pasteur-Chamberlain filter. Aliquot portions of the filtrate were then analyzed for ammonia and nitrates. The ammonia was deter- 
mined by adding concentrated sodium hydroxide, distilling, and titrating the distillate with tenth-normal hydrochloric acid. The nitrates were determined by the phenol-disulfonic-acid method, using the Schreiner colorimeter to read the intensity of color.

Ammonification. - To the soil used for ammonification tests was first added 0.5 per cent of dried blood. The manganese sulfate was added after the soil had been weighed out and placed in the culture bottles. Sufficient water was used as the solvent of the manganese sulfate to bring the soil in each culture to a moisture content of 25 per cent (dry basis). The cultures were incubated for one week, at the end of which extracts and determinations were made as described above. The results are given in tables 15 and 16 :

Table 15. Effect of Manganese Sulfate on Ammonification of Dried Blood in DUNKIRK SIL'T LOAM

(Cultures incubated for seven days)

\begin{tabular}{|c|c|c|}
\hline Parts per million of manganese added & $\begin{array}{c}\text { Nitrogen } \\
\text { as ammonia, } \\
\text { average of } \\
4 \text { cultures } \\
\text { (milligrams) }\end{array}$ & $\begin{array}{l}\text { Relative } \\
\text { amounts }\end{array}$ \\
\hline 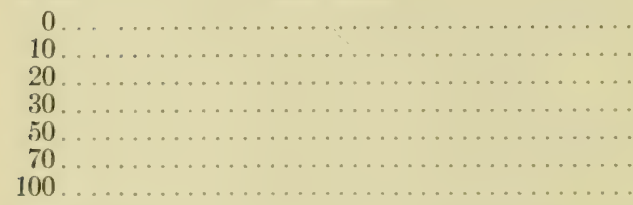 & $\begin{array}{l}34 \\
47 \\
53 \\
47 \\
54 \\
58 \\
67\end{array}$ & $\begin{array}{l}100 \\
138 \\
156 \\
138 \\
159 \\
170 \\
197\end{array}$ \\
\hline
\end{tabular}

Table 16. Effect of Manganese Sulfate and 20,000 Parts per Million of Calcium Carbonate on Ammonification of Dried Blood in Dunkirk Silt loam

(Cultures incubated for seven days)

\begin{tabular}{|c|c|c|}
\hline Parts per million of manganese added & $\begin{array}{c}\text { Nitrogen } \\
\text { as ammonia, } \\
\text { average of } \\
\text { t cultures } \\
\text { (milligrams) }\end{array}$ & $\begin{array}{l}\text { Relative } \\
\text { amounts }\end{array}$ \\
\hline $\begin{array}{r}0 \\
100 \ldots \ldots \ldots \ldots \ldots \ldots \\
1000 \ldots \ldots\end{array}$ & $\begin{array}{r}87 \\
96 \\
109\end{array}$ & $\begin{array}{l}100 \\
110 \\
125\end{array}$ \\
\hline
\end{tabular}


The addition of manganese sulfate to the soil resulted in a positive stimulation in the ammonifying power. The addition of calcium carbonate resulted in a greater stimulation than that caused by the manganese alone. The stimulation of the manganese is not so great in alkaline soil as in soil deficient in calcium. This is as would be expected, for the solubility of the manganese is decreased.

Nitrification.- To the soil used for nitrification tests, 220 parts per million of nitrogen in the form of ammonium sulfate was added. The calculated quantities of solutions of manganese and ammonium sulfate were mixed, and were added to the soil in the culture bottles together with sufficient water to bring the soil to a moisture content of 25 per cent (dry basis). The cultures were incubated for four weeks. At the end of this time the extracts and determinations were made as described, and the results, expressed as parts of nitrates per million parts of dry soil, are given in tables 17 and 18. The experimental error of this deter-

TABle 17. Effect of Manganese Sulfate on Nitrification of Ammonium Sulfate in Dunkirk Silt Loam

(Cultures incubated for thirty days)

\begin{tabular}{|c|c|c|}
\hline Parts per million of manganese added & $\begin{array}{l}\text { Nitrates, } \\
\text { average of } \\
4 \text { cultures } \\
\text { (parts per } \\
\text { million } \\
\text { of soil) }\end{array}$ & $\begin{array}{l}\text { Relative } \\
\text { amounts }\end{array}$ \\
\hline 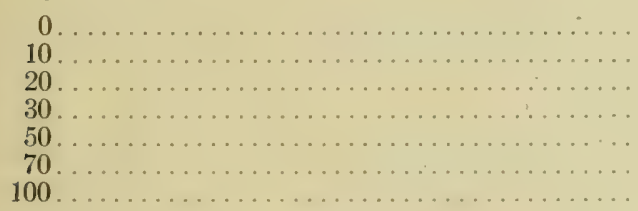 & $\begin{array}{l}234 \\
236 \\
252 \\
197 \\
156 \\
136 \\
122\end{array}$ & $\begin{array}{r}100 \\
101 \\
108 \\
84 \\
67 \\
58 \\
52\end{array}$ \\
\hline
\end{tabular}

mination is large, and the data given in the tables indicate that manganese sulfate in low concentrations did not affect the nitrifying power of the soil. In soils containing larger amounts of manganese, however, the nitrification was checked. 
Table 18. Effect of Manganese Sulfate and 20,000 Parts per Million of Calcium Carbonate on Nitrification of Ammonium Sulfate in Dunkirk Silt Loam (Cultures incubated for thirty days)

\begin{tabular}{|c|c|c|}
\hline Parts per million of manganese added & $\begin{array}{c}\text { Nitrates, } \\
\text { average of } \\
4 \text { cultures } \\
\text { (parts per } \\
\text { million } \\
\text { of soil) }\end{array}$ & $\begin{array}{l}\text { Relative } \\
\text { amounts }\end{array}$ \\
\hline $\begin{array}{r}0 \ldots \ldots \\
100 \ldots \ldots \\
1000 \ldots \ldots\end{array}$ & $\begin{array}{l}344 \\
326 \\
273\end{array}$ & $\begin{array}{r}100 \\
95 \\
79\end{array}$ \\
\hline
\end{tabular}

\section{Conclusions}

The experimental data here reported seem to justify the following conclusions:

1. Manganese salts added to water cultures affect the growth of wheat seedlings. The comparison of relative weights shows that when presented to the plant in high concentrations, both the sulfate and the chloride exert a toxic effect. In lower concentrations, manganese causes a marked stimulation.

2. The degree of toxicity is reduced by full nutrient solutions and the reduction is directly proportional to the concentration of the nutrient salts. Likewise, the food stored in the endosperms reduces the toxicity of the plant poisen.

3. The toxic influenee results in the browning of the roots and the bleaching of the leaves. The yellow leaves of the manganese plants contain more manganese than do the green ones.

4. Manganese salts added to soil form manganese dioxide in proportion to the basicity of the soil, and thus develop a power to oxidize organic matter as shown by the oxidation of aloin or phenolphthalin.

5. Manganese sulfate in water cultures stimulates the oxidizing power of the roots of wheat seedlings.

6. Low coneentrations of manganese sulfate were found to stimulate the ammonification of clried blood in soil. The nitrification of ammonium sulfate was inhibited. 


\section{LITERATURE CITED}

Aso, K. On the physiological influence of manganese compounds on plants. Tokyo Imp. Univ., Coll. Agr. Bul. 5:177-185. 1902-03.

__ On the practical application of manganous chlorid in riceculture. Tokyo Imp. Univ., Coll. Agr. Bul. 6:131-133. 1904-05.

Bartmann, Henry. Le manganèse en agriculture. Journ. agr. prat., n. s. IQ:115-117. 1910.

Bertrane. G. Sur les engrais catalytiques. Seventh Int. Congress Applied Chem., London Section, p. 159-162. 1909.

Brenchley, Miss W. E. The influence of copper sulphate and manganese sulphate upon the growth of barley. Ann. bot. 24:571-583. 1910.

Effect of manganese compounds. In Inorganic plant poisons and stimulants, p. 78-92. Cambridge agr. monographs. 1914.

Brown, P. E., And Minges, G. A. The effect of some manganese salts on ammonification and nitrification. Soil science 2:67-85. 1916.

Chittenden, F. J. The effect of manganese sulphate on the yield of turnips at Wisley. Roy. Hort. Soc. [London]. Journ. 4I : 94-96. 1915-16.

Crochetelle, J. Influence du sulfate de manganèse sur la germination. Journ. agr. prat., n. s. 26:398-399. 1913.

Dam, W. van. Use of manganese compounds as fertilizers. Chem. weekbl. 4:391-397. 1907. [Abstracted in Exp. sta. rec. 19:523-524. 1908.]

Ehrenberg, P., AND Schultze, K. Fertilization with manganese. Journ. Landw. 64:37-129. [Cited in Chem. abs. II :1872. 1917.]

Feilitzen, Hualmar von. Kann man auf dem freien Felde einen günstigen stimulierenden Einfluss auf die Entwickelung der Kulturpflanzen durch kleine Mengen Mangansalze wahrnehmen? Journ. Landw. $55: 289-292.1907$.

Grue, P. L. Chlorosis of pineapples induced by manganese and carbonate of lime. Science n. s. 44:855-857. 1916.

Greaves, J. E. The influence of salts on the bacterial activities of the soil. Soil science $2: 443-480 . \quad 1916$.

Gregario, Rocasolano Antonio de. Catalytic fertilizer. Rev. Real. Acad. Sci. I4 :681-693. 1916. [Cited in Chem. ahs. II :1511. 1917.]

Houtermans, Elsa. Über angebliche Beziehungen zwischen der Salpetersäureassimilation und der Manganabscheidung in der Pflanze. K. Akad. Wiss. [Vienna], Math. Naturw. Kl. Sitzber. I2I :801-831. 1912. [Cited in Exp. sta. rec. 30:30. 1914.] 
Jadin. F., And Astruc, A. Quelques déterminations quantitatives du manganèse dans le règne végétal. Acad. Sci. [Paris]. Compt. rend. I55:406-408. 1912 .

Javiliter, Maurice. Le zinc chez les plantes. Recherches sur sa présence et son rôle. Inst. Pasteur. Ann. 22 :720-727. 1908.

Johnson, Maxwell E. Manganese as a cause of the depression of the assimilation of iron by pineapple plants. Journ. indus. and eng. chem. $9: 47-49.1917$.

Kastle, J. H. The oxidases and other oxygen-catalysts concerned in biologica! oxidations. U. S. Hygienic Laboratory, Public Health and Marine-Hospital Service. Bul. 59:1-164. 1910.

Katayaisa, T. On the degree of stimulating action of manganese and iron salts on barley. Tokyo Imp. Univ., Coll. Agr. Bul. 7:91-93. 1906-08.

Kelley, W. P. The function and distribution of manganese in plants and soils. Hawaii Agr. Exp. Sta. Bul. 26:1-56. 1912.

Leoncini, Grovanni. Azione del biossido di manganese nella vinificazione in rapporto all' acido tartarico. Staz. Sper. Agr. Ital. Giorn. uff. $43: 33-45.1910$.

Loew, Oscar, and Honda, Seiroku. Ueber den Einfluss des Mangans auf Wald äume. Tokyo Im!). Univ., Coll. Agr. Bul. 6:125-130. 1904-05.

Loew, O., AND SAWA, S. On the action of manganese compounds on plants. Tokyo Imp. Univ., Coll. Agr. Bul. 5 : 161-172. 1902-03.

McCallum, W. B. Plant physiology and pathology. Univ. Arizona Agr. Exp. Sta. Rept. $20: 583-586.1909$.

McCool, M. M. The action of eertain nutrient and non-nutrient bases on plant growth. Cornell Univ. Agr. Exp. Sta. Memoir 2 :113-216. 1913.

Maneli, E. Influenza del magnesio sopra la formazione della clorofilla. Soc. Ital. Prog. Sci. Atti 5:793-799. 1912. [Abstracted in Bot. Centbl. I22:200. 1913.]

Masoni, Giulio. Saggio sul!' azione del solfato di manganese in rapporto alla vegetazione. Staz. Sper. Agr. Ital. Org. uff. 44:85-112. 1911.

_ L La reazione alcalina provocata dagli acidi nelle terre in rapporto alla nutrizione delle piante. Staz. Sper. Agr. Ital. Org. uff. $49: 132-149.1916$.

Mazé, P. Note sur les chloroses des végétaux. Soc. biol. [Paris]. Compt. rend. 66 $: 539-541.1914$.

Mrcheels, H., a.do De Hew, P. Note an sujet de l'action stimulante du manganèse sur lat germination. Acarl. Roy. Belgique, Cl. Sci. Bul. 1906 : 288-289. 1906. 
Montanari, C. Azione degli elementi oligodinamici sui batteri della nitrificazione. Staz. Sper. Agr. Ital. Org. uff. 47:441-448. 1914.

Montemartini, Luigi. L'azione eccitante del solfato di manganese e del solfato di rame sopra le piante. Staz. Sper. Agr. Ital. Org. uff. $44: 564-571.1911$.

Munerati, O., Messadroli, G., and Zapparoli, T. V. Influenza di alcune sostanze oligodinamiche e di altre poco usate sullo sviluppo della barbabietola da zucchero. Gli errori sperimentali. Staz. Sper. Agr. Ital. Org. uff. 46:486-498. 1913.

NAGAOKA, M. On the stimulating action of manganese upon rice. III. Tokyo Imp. Univ., Coll. Agr. Bul. 7 :77-81. 1906-08.

Nottin, P. Étude agrologique du manganèse. Acad. Sci. [Paris]. Compt. rend. I55: 1167-1169. 1912.

Oraru, D. Action favorable du manganèse sur la bactérie des légumineuses. Acad. Sci. [Paris]. Compt. rend. I6o :280-283. 1915.

Pfeiffer, Th., and Blanck, E. Beitrag zur Frage über die Wirkung des Mangans auf das Pflanzenwachstum. Landw. Vers. Stat. $77: 33-66$. 1912.

Pugliese, Alfredo. Biochemistry of manganese. Inst. incoragg. Napoli. Atti 65:289-328. 1913. [Cited in Chem. abs. 9:641-642. 1915.]

Ray, Julien, and Pradier, G. Nitrate d'uranium et sulfate de manganèse : leur emploi avantageux en arboriculture fruitière. Journ. agr. prat., n. s. I8:311-312. 1909.

Rousset, Henri. Les engrais "manganés." Ann. sci. agron., 3 ser. $4^{2}: 81-111.1909$.

Salomone, Giovanni. Manganese e lo sviluppo delle piante. Seconda nota. Staz. Sper. Agr. Ital. Giorn. uff. 40:97-117. 1907.

Schreiner, Oswald, and Failyer, George H. Colorimetric, turbidity, and titration methods used in soil investigations. U. S. Bur. Soils. Bul. 31 : 1-60. 1906.

Schreiner, Oswald, and Reed, Howard S. The rôle of oxidlation in soil fertility. U. S. Bur. Soils. Bul. 56:1-52. 1909.

Schreiner, Oswald, and Shorey, Edmund C. The isolation of harmful organic substances from soils. U. S. Bur. Soils. Bul. 53:1-53. 1909.

Schreiner, Ostwald, Sullivan, M. X., and Reid, F. R. Studies in soil oxidation. U. S. Bur. Soils. Bul. $73: 1-57.1910$.

Skinner, J. J., ANd Reid, F. R. The action of manganese under acid and neutral soil conditions. U. S. Dept. Agr. Bul. 441:1-12. 1916.

Skinner, J. J., ANd Sullivav, M. X. The action of manganese in soils. U. S. Dept. Agr. Bul. 42 : 1-32. 1914. 
Sullivan, M. X., and Reid, F. R. Studies in soil catalysis. U. S. Bur. Soils. Bul. $86: 1-31.1912$.

Sullivan, M. X., and Robinson, W. O. Manganese as a fertilizer. U. S. Bur. Soils. Cire. $75: 1-3.1913$.

Takeuchi, T. On differences of susceptibility of plants to stimulation. Tokyo Imp. Univ., Coll. Agr. Journ. I :207-210., 1909-13.

Tottingham, W. E., AND BECK, A. J. Antagonism between manganese and iron in the growth of wheat. Plant world I9:359-370. 1916.

U CHIYAMA, S. Influence of stimulating compounds upon the crops under different conditions. Imp. Cent. Agr. Exp. Sta. [Japan]. Bul. $\mathbf{I}^{2}: 37-79$. 1907.

Vincent, V. Circulation du manganèse dans les eaux naturelles. Acad. Sci. [Paris]. Compt. rend. I62 :259-261. 1916.

Voelcher, J. Augustus. Pot-culture experiments, 1903. [Woburn.] Roy. Agr. Soc. England. Journ. $65: 306-315.1904$.

Woods, Albert F. The destruction of chlorophyll by oxidizing enzymes. Centbl. Bakt., Par., und Infekt. 5 :745-754. 1899.

Memoir 17, The Translocation of Calcium in a Soil, the second preceding number in this series of publications, was mailed on February $12,1919$. 



\section{LIBRARY OF CONGRESS}

|||||||||||||||||||||||||||||||||||||||||||||||||||

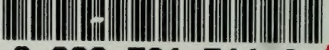

0002781511 A 